\title{
Neuropsychological and neurological outcome after relapse of lymphoblastic leukaemia
}

\author{
D Christie, M Battin, A D Leiper, J Chessells, F Vargha-Khadem, B G R Neville
}

\begin{abstract}
Fourteen children who relapsed after initial remission of leukaemia were studied. Six received a second course of cranial radiotherapy, while the remaining eight children were given total body irradiation before bone marrow transplantation. The postirradiation somnolence syndrome was common after cranial radiotherapy. All children had $\mathrm{mild} / \mathrm{soft}$ neurological signs, mostly of coordination. None had a major motor disability. All but the youngest child had cataracts; two children required an operation for these. All children were growth hormone deficient.

Verbal IQ, attention, and concentration were selectively reduced (with respect to normative levels). The time between the two treatments, age at relapse, and higher doses of radiotherapy all correlated with cognitive outcome, with girls showing greater impairments than boys.

Only two children were performing at age appropriate levels on measures of academic achievement. It is concluded that neurological and neuropsychological morbidity is significantly increased by the current treatments prescribed after the relapse of leukaemia.

(Arch Dis Child 1994; 70: 275-280)
\end{abstract}

The use of presymptomatic central nervous system (CNS) directed radiotherapy and chemotherapy in childhood leukaemia over the past 20 years has reduced the incidence of CNS relapse and contributed to the steady increase in long term survival. ${ }^{12}$ As more children survive, however, it has become apparent that a minority have significant late effects of treatment which include lowering of their IQ and memory impairment, ${ }^{34}$ and calcification and white matter changes on brain imaging. ${ }^{56}$ Mild neurological signs are seen in a proportion. ${ }^{78}$ The pathogenesis of damage has been attributed to vascular and biochemical mechanisms as a result of radiotherapy and chemotherapy. ${ }^{5910}$ Concern about this issue has led to a reduction in cranial radiotherapy doses from 2400 to $1800 \mathrm{cGy}$, greater fractionation of the dose, and subsequently avoidance of cranial radiotherapy in children less than 2 years old, who appear to be the most vulnerable group. ${ }^{11}$

Despite the use of routine CNS directed treatment, $5-10 \%$ of children have a CNS relapse as a first event. ${ }^{12}$ The second course of treatment has included radiotherapy, either as a second course of cranial radiotherapy, or more recently total body irradiation given as preconditioning before bone marrow transplantation. To date there is relatively little information available about the morbidity of treatment that includes double irradiation. We have examined the neurological, neuropsychological, and educational outcome in a group of long term survivors of retrieval therapy after relapse in childhood leukaemia.

\section{Subjects and methods}

Fourteen children who had received two or more courses of radiotherapy agreed to participate in the study. Initial CNS directed treatment consisted of cranial irradiation (1800-2400 cGy) and intrathecal methotrexate. Six had a second course of cranial (with or without craniospinal) radiotherapy and eight had total body irradiation. All had further intrathecal methotrexate. Two children received high dose intravenous methotrexate and three received intrathecal triple injections (cytosine, hydrocortisone, and methotrexate). Table 1 gives the details of each child and their treatments. Two did not complete the neurological assessment due to relapse and non-attendance.

\section{PROCEDURES}

Neurology

Neurological evaluation consisted of a parent and patient interview, review of the clinical records, and a physical examination including a neurological assessment. Praxis was tested by asking the child to copy a range of simple and complex gestures. ${ }^{13}$ Coordination was tested by rapid finger/thumb opposition, dysdiaokinesis, finger-nose testing, and finger opposition. Hand grip strength was measured using a Kiddie hand dynamometer. ${ }^{14}$ Three readings of grip strength (in kilograms) were obtained from each hand and the mean power for each hand was calculated. The non-dominant hand was always tested first. Dexterity was measured on a peg sorting task. ${ }^{15}$ Where possible the results of computed tomography or magnetic resonance imaging were obtained.

\section{Neuropsychology}

The Wechsler intelligence scales (WISC-R ${ }^{16}$ or WAIS-R ${ }^{17}$ ) were administered to evaluate intellectual ability. Three factors were calculated from the scales: verbal comprehension, perceptual organisation, and freedom from distractibility. ${ }^{18}$ The Wechsler memory scale 
Table 1 Clinical details of 14 patients with leukaemia who relapsed and their treatment directed to the central nervous system

\begin{tabular}{|c|c|c|c|c|c|c|c|c|}
\hline $\begin{array}{l}\text { Patient } \\
\text { No }\end{array}$ & Sex & $\begin{array}{l}\text { Test } \\
\text { age }\end{array}$ & $\begin{array}{l}\text { Age at } \\
\text { diagnosis } \\
\text { (months) }\end{array}$ & $\begin{array}{l}\text { Age at } \\
\text { relapse } \\
\text { (months) }\end{array}$ & $\begin{array}{l}\text { Site of } \\
\text { relapse }\end{array}$ & $\begin{array}{l}\text { Dose of } \\
\text { first course of } \\
\text { radiotherapy } \\
(c G y)\end{array}$ & $\begin{array}{l}\text { Dose of } \\
\text { second course of } \\
\text { radiotheraphy† } \\
(c G y)\end{array}$ & $\begin{array}{l}\text { ITMTX } \\
\text { injections } \$\end{array}$ \\
\hline $\begin{array}{l}1 \\
2\end{array}$ & $\begin{array}{l}\mathrm{F} \\
\mathrm{F}\end{array}$ & $\begin{array}{l}191 \\
184\end{array}$ & $\begin{array}{l}84 \\
83\end{array}$ & $\begin{array}{l}115 \\
109\end{array}$ & $\begin{array}{l}\text { CNS } \\
\text { CNS }\end{array}$ & $\begin{array}{l}1800 \\
2400\end{array}$ & \multirow{4}{*}{$\begin{array}{l}2400 \text { CRT } \\
2000 \text { CRT; } \\
2000 \text { Spine } \\
2400 \text { CRT } \\
2400 \text { CRT } \\
\text { (a) } 2100 \text { CRT; } \\
\text { (b) } 1000 \text { TBI } \\
1600 \text { CRT } \\
\text { (a) } 1200 \text { TBI; } \\
\text { (b) No RT } \\
1000 \text { TBI } \\
1000 \text { TBI } \\
1200 \text { TBI } \\
1200 \text { TBI } \\
1200 \text { TBI } \\
1200 \text { TBI } \\
\text { (a) } 1000 \text { TBI; } \\
\text { (b) } \ddagger\end{array}$} & $\begin{array}{l}20 \\
33\end{array}$ \\
\hline $\begin{array}{l}3 \\
4 \\
5\end{array}$ & $\begin{array}{l}\mathrm{F} \\
\mathrm{M} \\
\mathrm{M}\end{array}$ & $\begin{array}{l}133 \\
150 \\
147\end{array}$ & $\begin{array}{l}54 \\
19 \\
34\end{array}$ & $\begin{array}{l}78 \\
50 \\
\text { (a) } 79 \text {; } \\
\text { (b) } 118\end{array}$ & $\begin{array}{l}\text { CNS } \\
\text { BM/CNS } \\
\text { (a) CNS; } \\
\text { (b) BM }\end{array}$ & $\begin{array}{l}1800 \\
1800 \\
1800\end{array}$ & & $\begin{array}{l}24 \\
49 \\
38+3 \mathrm{IV}\end{array}$ \\
\hline $\begin{array}{l}6 \\
7\end{array}$ & $\begin{array}{l}M \\
M\end{array}$ & $\begin{array}{l}213 \\
125\end{array}$ & $\begin{array}{l}70 \\
59\end{array}$ & $\begin{array}{l}84 \\
\text { (a) } 117 \text {; } \\
\text { (b) } 130\end{array}$ & $\begin{array}{l}\text { CNS } \\
\text { (a) } \mathrm{BM}+\mathrm{T} \text {; } \\
\text { (b) } \mathrm{BM}\end{array}$ & $\begin{array}{l}1760 \\
1800\end{array}$ & & $\begin{array}{l}23+12 \mathrm{IV} \\
20\end{array}$ \\
\hline $\begin{array}{r}8 \\
9 \\
10 \\
11 \\
12 \\
13 \\
14\end{array}$ & $\begin{array}{l}M \\
M \\
M \\
M \\
M \\
F \\
M\end{array}$ & $\begin{array}{r}229 \\
153 \\
118 \\
155 \\
132 \\
96 \\
204\end{array}$ & $\begin{array}{l}41 \\
44 \\
45 \\
42 \\
53 \\
28 \\
72\end{array}$ & $\begin{array}{l}121 \\
105 \\
60 \\
105 \\
96 \\
79 \\
\text { (a) } 105 \text {; } \\
\text { (b) } 133 \text {; } \\
\text { (c) } 168 \text {; } \\
\text { (d) } 194 ; \\
\text { (e) } 206\end{array}$ & $\begin{array}{l}\text { BM } \\
\text { BM } \\
\text { CNS } \\
\text { BM } \\
\text { BM } \\
\text { BM/CNS } \\
\text { (a) BM/CNS; } \\
\text { (b) CNS: } \\
\text { (c) CNS; } \\
\text { (d) CNS; } \\
\text { (e) CNS/BM }\end{array}$ & $\begin{array}{l}2400 \\
2000 \\
2400 \\
1800 \\
1800 \\
2400 \\
1800\end{array}$ & & $\begin{array}{l}7 \\
8+3 \mathrm{Tr} \\
13 \\
11 \\
15 \\
18+3 \mathrm{Tr} \\
62+13 \mathrm{Tr}\end{array}$ \\
\hline \multicolumn{2}{|c|}{ Mean (SD) } & $159 \cdot 3(39)$ & $52(19 \cdot 8)$ & $94.9(18 \cdot 7)$ & & $1981(290)$ & $1676(624)$ & $21(12)$ \\
\hline
\end{tabular}

${ }^{\star} \mathrm{CNS}=$ central nervous system; $\mathbf{B M}=$ bone marrow; $\mathrm{T}=$ testicular.

$+C R T=$ cranial radiotherapy TBI $=$ total body irradiation.

FNS directed treatment delivered via an intraventricular reservoir.

$\hat{\S}=$ Total number of intrathecal methotrexate (ITMTX) injections given: $\mathrm{Tr}=$ triple; $\mathrm{IV}=$ intravenous methotrexate.

(WMS) with age correction for children ${ }^{19}$ was given to assess memory. Children who were at least 12 years old were administered the logical memory subtest of the scale (form I). Children less than 12 years old at the time of testing were given two easier stories. ${ }^{20}$ In addition to the overall memory quotient, calculated according to the WMS manual, two subtests were selected to provide measures of immediate and delayed recall for verbal and visual information.

The first subtest, paired associate learning, was administered as described in the WMS manual and scored for immediate recall after each of the three presentations of the 10 paired associates. The set of 10 pairs consists of six pairs of related items (for example, up-down) and four pairs of unrelated items (for example, cabbage-pen). A weighted score was calculated which makes an adjustment for easier pairs. Delayed recall was measured after a 90 minute filled delay. The delayed recall was scored out of 10 .

The second subtest was visual reproduction. The immediate reproduction of geometric designs was scored as described in the WMS manual. In addition, after a 40 minute delay filled with interpolated tasks, subjects were asked to draw the geometric designs from memory.

The British picture vocabulary scale ${ }^{21}$ and the test for reception of grammar $^{22}$ were administered to provide measures of receptive language ability.

\section{Educational attainments}

Reading, spelling, and number skills were assessed using standardised tests. The Schonell single word reading test ${ }^{23}$ and the Neale analysis of reading ability (revised) ${ }^{24}$ provided measures of reading speed, accuracy, and comprehension. The Schonell spelling test $^{25}$ and the British abilities scale basic number skills subtest ${ }^{26}$ were also administered.

\section{STATISTICS}

The psychological data were subjected to statistical analysis using the statistical package for social sciences (SPSS/PC).

Two forms of analysis were performed. The first involved comparing the mean scaled scores on the IQ memory, and language measures with the assumed normal population mean using a one sample $t$ test. The second analysis looked at the relation between performance and the treatment and diagnostic variables. Performance on all outcome measures was correlated with six treatment variables. Four variables were related to the child: gender, age at diagnosis, age at relapse, and the time between the two courses of radiotherapy. Two variables were related to the treatment: total dose of radiotherapy and number of methotrexate injections. A forward stepwise multiple regression was then used to look at the relative contribution of all the treatment variables and calculate the best fitting model to each of the outcome measures.

For each of the standardised reading, spelling, and maths tests age equivalent performance levels were calculated.

\section{Results}

GENERAL SYMPTOMS

After the initial radiotherapy treatment, nine $(64 \%)$ children had postirradiation somnolence syndrome characterised by lethargy, ranging from mild drowsiness to prolonged periods of sleep, irritability, low grade fever, nausea, and vomiting. There was no case of associated ataxia or seizures. There was no historical evidence of myelopathy. After the second dose of cranial radiotherapy, all six $(100 \%)$ children had symptoms of 
Table 2 Details of neurological assessments of 12 patients. Grip strength and dexterity data are given as standard deviation units below normative levels

\begin{tabular}{|c|c|c|c|c|c|c|c|c|c|}
\hline \multirow[b]{2}{*}{$\begin{array}{l}\text { Patient } \\
\text { No }\end{array}$} & \multirow[b]{2}{*}{ Reflexes } & \multicolumn{2}{|c|}{ Gesture imitation } & \multirow[b]{2}{*}{ Coordination } & \multicolumn{2}{|c|}{ Grip strength } & \multicolumn{2}{|l|}{ Dexterity } & \multirow[b]{2}{*}{ Additional problems } \\
\hline & & Complex & Simple & & Dominant & $\begin{array}{l}\text { Non- } \\
\text { dominant }\end{array}$ & Dominant & $\begin{array}{l}\text { Non- } \\
\text { dominant }\end{array}$ & \\
\hline 1 & Brisk & Poor & Poor & Normal & $>2$ & $>2$ & Normal & Normal & $\begin{array}{l}\text { Retinitis (left eye), left eye VA } \\
6 / 36, \text { migrainous headaches, } \\
\text { height, weight, head circum- } \\
\text { ference }<3 \text { rd centile, thin hair }\end{array}$ \\
\hline 2 & Brisk & Poor & Poor & Poor & $>2$ & $>3$. & Normal & $>2$ & $\begin{array}{l}\text { Migrainous headaches, height, } \\
\text { weight, head circumference } \\
<3 \text { rd centile, thin hair }\end{array}$ \\
\hline $\begin{array}{l}4 \\
5\end{array}$ & $\begin{array}{l}\text { Brisk } \\
\text { Brisk }\end{array}$ & $\begin{array}{l}\text { Normal } \\
\text { Poor }\end{array}$ & $\begin{array}{l}\text { Normal } \\
\text { Poor }\end{array}$ & $\begin{array}{l}\text { Normal } \\
\text { Normal }\end{array}$ & $\begin{array}{l}\text { Normal } \\
\text { Normal }\end{array}$ & $\begin{array}{l}\text { Normal } \\
>1\end{array}$ & $\begin{array}{l}\text { Normal } \\
\text { Normal }\end{array}$ & $\begin{array}{l}>1 \\
\text { Normal }\end{array}$ & \\
\hline 6 & Normal & Poor & Poor & Poor & $>1$ & $>1$ & Normal & $>2$ & $\begin{array}{l}\text { Impaired sensation in legs } \\
\text { (asymptomatic) }\end{array}$ \\
\hline $\begin{array}{l}7 \\
8\end{array}$ & $\begin{array}{l}\text { Brisk } \\
\text { Brisk }\end{array}$ & Normal & Normal & Normal & $>1$ & $>1$ & Normal & Normal & Frequent falls \\
\hline 9 & Brisk & Normal & Normal & Normal & Normal & Normal & Normal & Normal & $\begin{array}{l}\text { Mild finger wandering } \\
\text { (right>left) }\end{array}$ \\
\hline $\begin{array}{l}10 \\
11\end{array}$ & $\begin{array}{l}\text { Brisk } \\
\text { Normal }\end{array}$ & $\begin{array}{l}\text { Normal } \\
\text { Normal }\end{array}$ & $\begin{array}{l}\text { Normal } \\
\text { Normal }\end{array}$ & $\begin{array}{l}\text { Normal } \\
\text { Normal }\end{array}$ & $\begin{array}{l}\text { Normal } \\
\text { Normal }\end{array}$ & $\begin{array}{l}\text { Normal } \\
\text { Normal }\end{array}$ & $\begin{array}{l}\text { Normal } \\
\text { Normal }\end{array}$ & $\begin{array}{l}\text { Normal } \\
\text { Normal }\end{array}$ & Mild joint laxity \\
\hline 12 & Normal & Poor & Normal & Normal & Normal & Normal & Normal & Normal & $\begin{array}{l}\text { Abnormal gait, weak eversion of } \\
\text { feet, dry eyes }\end{array}$ \\
\hline 13 & Brisk & Poor & Normal & Normal & Normal & $>1$ & Normal & Normal & $\begin{array}{l}\text { Stiff leg gait, broken eye follow- } \\
\text { ing movements (left eye) }\end{array}$ \\
\hline
\end{tabular}

somnolence, whereas after total body irradiation only two $(25 \%)$ children were reported to have had mild symptoms.

All children had growth hormone deficiency which was monitored and treated, when appropriate, with growth hormone replacement therapy.

Headaches were reported as a problem in two girls, both of whom received a second dose of cranial radiotherapy. They also had a history of poor emotional adjustment. All children except the youngest had some degree of cataract formation. Two children have had an operation (with lens replacement) and one has photophobia requiring the use of dark glasses.

\section{NEUROLOGICAL FINDINGS}

Table 2 gives details of the neurological results. All of the 12 children seen for neurological assessment had at least one neurological sign, with seven $(58 \%)$ of the children having two or more.

Nine (64\%) had mild pyramidal signs with brisk reflexes that were more marked in the legs. Nine $(64 \%)$ children had problems with fine motor control, with three showing difficulty with both complex and simple gesture imitation. Two of the children with dyspraxia also showed poor coordination as tested by rapid finger/thumb opposition, dysdiaokinesis, finger-nose testing, and finger opposition. One boy had an asymptomatic sensory deficit in his legs with difficulty in

Table 3 Mean (SD) (range) of IQ, language, and memory scores. Number (\%) of children scoring more than 1 SD below the mean (below average performance) is also given

\begin{tabular}{lcl}
\hline & $\begin{array}{l}\text { Mean }(S D) \\
\text { range score }\end{array}$ & $\begin{array}{l}\text { No (\%) scoring in the } \\
\text { below average range }\end{array}$ \\
\hline Verbal comprehension & $88(15)+(60-113)$ & $7(50)$ \\
Perceptual organisation & $95(21)(47-124)$ & $3(21)$ \\
Freedom from distractibility & $84(18)+(40-111)$ & $5(36)$ \\
British picture vocabulary scale & $89(22)(42-128)$ & $6(43)$ \\
Test for reception of grammar & $100(20)(59-132)$ & $2(14)$ \\
Memory quotient (n=13) & $89(19)(59-122)$ & $6(46)$ \\
\hline
\end{tabular}

^Expected: $16 \%$.

tp<0.05, one sample $t$ test $($ mean $=100)$. eliciting tendon jerks and impaired sensation to light touch, proprioception, and vibration, but no detectable weakness or gait disorder. One patient had evidence of old unilateral retinitis and poor visual acuity in the affected eye. She was thought to have had cytomegalovirus infection during intensive chemotherapy.

Grip strength was reduced in both hands for four children, with two children showing a mild reduction in their non-dominant hands.

Three children had impaired peg sorting when using the non-dominant hand.

\section{SCAN DETAILS}

Computed tomography was performed on five children before the second dose of radiotherapy. Only one of these was reported as having enlarged ventricles and widened cortical sulci.

Magnetic resonance imaging was performed on five children after the second dose of radiotherapy. Varying degrees of ventricular enlargement were noted in all scans. Two children had diffuse white matter changes in the parietal lobes and two had damage mainly in the frontal lobes. Diffuse parenchymal damage was reported in one child.

\section{NEUROPSYCHOLOGY}

Table 3 gives the three deviation IQ scores, memory quotient, receptive vocabulary, and comprehension of grammar scaled scores. Using a one sample $t$ test, verbal comprehension and freedom from distractibility were significantly different from a normal mean of 100 (verbal comprehension $t=2 \cdot 846, \mathrm{p}<0.05$; freedom from distractibility $t=3.161, \mathrm{p}<0.05)$. The normal standard deviation (SD) is 15; therefore, $68 \%$ of children in a normal population would have a score between 85 and 115 with only $16 \%$ scoring more than 1 SD below average (that is, less than 85). Table 3 also shows the number (and percentage) of children whose deviation quotient was more 
Table 4 Correlation matrix coefficients (one tailed p values) for outcome measures and treatment variables. Also shown are the variables in the equation for stepwise forward multiple regression with standardised $\beta$ values, significance level, and adjusted $R^{2}$

\begin{tabular}{|c|c|c|c|c|c|c|c|c|c|c|}
\hline & $\begin{array}{l}\text { Age at } \\
\text { diagnosis }\end{array}$ & $\begin{array}{l}\text { Age at } \\
\text { relapse }\end{array}$ & $\begin{array}{l}\text { Time } \\
\text { between } \\
\text { treatments }\end{array}$ & $\begin{array}{l}\text { Total cranial } \\
\text { radiotherapy } \\
\text { dose }\end{array}$ & $\begin{array}{l}\text { Intrathecal } \\
\text { methotrexate } \\
\text { injections }\end{array}$ & Gender & $\begin{array}{l}\text { Variable } \\
\text { in } \\
\text { equation }\end{array}$ & $\beta$ & $\begin{array}{l}\text { Significance } \\
\text { level }\end{array}$ & $\begin{array}{l}\text { Adjusted } \\
R^{2}\end{array}$ \\
\hline $\begin{array}{l}\text { Verbal } \\
\text { comprehension }\end{array}$ & $-0.436(0.068)$ & $0.351(0.12)$ & $0.769(0.001)$ & $-0.448(0.062)$ & $-0.329(0.136)$ & $0.435(0.068)$ & $\begin{array}{c}\text { Time between } \\
\text { treatments }\end{array}$ & 0.769 & 0.0021 & 0.555 \\
\hline $\begin{array}{l}\text { Perceptual } \\
\text { organisation }\end{array}$ & $-0.378(0 \cdot 101)$ & $0.329(0.136)$ & $0.691(0.004)$ & $-0.631(0.01)$ & $-0.401(0.087)$ & $0.469(0.053)$ & $\begin{array}{l}\text { Time between } \\
\text { treatments }\end{array}$ & 0.690 & 0.0089 & 0.429 \\
\hline $\begin{array}{l}\text { Freedom from } \\
\text { distractibility }\end{array}$ & $-0 \cdot 277(0 \cdot 169)$ & $0.375(0.09)$ & $0.624(0.009)$ & $-0 \cdot 279(0 \cdot 167)$ & $-0.414(0.07)$ & $0.502(0.034)$ & $\begin{array}{c}\text { Time between } \\
\text { treatments }\end{array}$ & 0.623 & 0.017 & 0.338 \\
\hline Memory quotient & $-0 \cdot 137(0.321)$ & $0.58(0.015)$ & $0.699(0.003)$ & $-0.452(0.052)$ & $-0 \cdot 289(0 \cdot 158)$ & $0.599(0.012)$ & $\begin{array}{c}\text { Time between } \\
\text { treatments }\end{array}$ & 0.699 & 0.0054 & 0.44 \\
\hline $\begin{array}{l}\text { Verbal memory } \\
\text { Immediate }\end{array}$ & $-0.044(0.44)$ & $0.506(0.032)$ & $0.528(0.026)$ & $-0 \cdot 237(0 \cdot 207)$ & $-0 \cdot 214(0 \cdot 231)$ & $0.341(0.116)$ & $\begin{array}{l}\text { No variables } \\
\text { entered in the } \\
\text { equation }\end{array}$ & & & \\
\hline Delayed & $0.289(0.157)$ & $0.444(0.056)$ & $0.148(0.307)$ & $-0 \cdot 268(0 \cdot 177)$ & $-0.412(0.072)$ & $0.115(0.348)$ & $\begin{array}{l}\text { No variables } \\
\text { entered in the } \\
\text { equation }\end{array}$ & & & \\
\hline $\begin{array}{l}\text { Visual memory } \\
\text { Immediate }\end{array}$ & $-0.082(0.39)$ & $0.485(0.039)$ & $0.562(0.018)$ & $-0 \cdot 198(0 \cdot 258)$ & $-0.299(0 \cdot 149)$ & $0.227(0.218)$ & $\begin{array}{l}\text { Time between } \\
\text { treatments }\end{array}$ & 0.561 & 0.0366 & $0 \cdot 258$ \\
\hline Delayed & $-0.05(0.43)$ & $0.537(0.029)$ & $0.566(0.022)$ & $-0 \cdot 198(0 \cdot 258)$ & $-0.291(0 \cdot 168)$ & $0.311(0.151)$ & $\begin{array}{c}\text { Time between } \\
\text { treatments }\end{array}$ & 0.565 & 0.044 & 0.258 \\
\hline $\begin{array}{l}\text { British picture } \\
\text { vocabulary } \\
\text { scale }\end{array}$ & $-0.518(0.029)$ & $0.252(0.192)$ & $0.785(0.000)$ & $-0.502(0.034)$ & $-0.246(0 \cdot 198)$ & $0.310(0.14)$ & $\begin{array}{l}\text { Time between } \\
\text { treatments }\end{array}$ & $0 \cdot 784$ & 0.0009 & 0.584 \\
\hline $\begin{array}{l}\text { Test for reception } \\
\text { of grammar }\end{array}$ & $-0.099(0.367)$ & $0.573(0.016)$ & $0.669(0.004)$ & $-0.420(0.067)$ & $-0.195(0.253)$ & $0.385(0.087)$ & $\begin{array}{l}\text { Time between } \\
\text { treatments }\end{array}$ & 0.668 & 0.0089 & 0.401 \\
\hline
\end{tabular}

*Significant.

than $1 \mathrm{SD}$ below average (that is, less than 85).

\section{RELATION BETWEEN TREATMENT VARIABLES AND OUTCOME}

Table 4 shows the correlation matrix for the IQ deviation quotients, memory quotient, memory subtests, and the language measures. The time between initial diagnosis and first relapse was highly correlated with all measures except for delayed verbal memory. Age at relapse was significantly correlated with the memory quotient, immediate verbal and visual memory, and delayed visual memory. Grammatical comprehension was also significantly correlated with age at relapse. Age at diagnosis was only correlated with receptive vocabulary. The total dose of radiotherapy was correlated with the perceptual organisation factor and receptive vocabulary. Girls performed at lower levels than boys, with gender significantly correlated with the freedom from distractibility factor and the memory quotient.

To examine the relative effect that the treatment variables have on the outcome measures a stepwise forward multiple regression was completed. The time between treatment was the only significant factor for each of the psychological outcome measures, except for the subtest measuring immediate and delayed verbal memory. The standardised $\beta$ regression coefficients, significance values, and adjusted $R^{2}$ are given in table 4 .

\section{EDUCATIONAL AND SOCIAL EFFECTS}

Parental concern was expressed over poor memory and concentration in $11(79 \%)$ children. All but three children had periods of prolonged absence from school, missing between six months and one year, with one child away from school for two years. Table 5 gives performance on the attainment measures for each child. Only three children are functioning at age appropriate levels in the attainment measures. The remaining children all show delays of two years or more in reading and spelling with seven $(50 \%)$ delayed in reading, spelling, and maths. The amount of time away from school and whether extra help was provided is also given in table 5 , with educational achievements and current employment status.

At the time of testing five of the 14 long term survivors were at or above school leaving age. Only one stayed on at school to take A level $(18+)$ examinations. The remaining four left school with two or three low grade passes in exams taken at 16. Two of these (both girls) reported being unhappy at school and had been bullied and needed counselling for help with anxiety and poor self esteem. They were small (below the third centile) as a result of growth hormone deficiency and their hair was thin and wispy. One continues to have anxiety attacks but, with support, has returned to college to resit exams. The other girl has been unsuccessful in obtaining employment. One young man is on a government training scheme. The young man (case 14) who had relapsed four times spent most of his time watching television and since completion of this study has relapsed and died. Of the nine children still at school, two were doing well and five had statements of special educational needs. The parents of the remaining two children were attempting to obtain extra help from the school and education authorities.

\section{Discussion}

The children reported in this study, who had undergone additional treatment for leukaemia after relapse, show evidence of growth impairment, intellectual dysfunction, and a range of minor neurological signs.

On returning to school all but three children received some form of extra help, either in a separate unit or on an individual basis in the 
Table 5 Age of initial diagnosis, relapse, and testing with time missed from school. Age equivalent performance levels, exam results (if taken), and current educationallemployment status (ages are in years:months)

\begin{tabular}{|c|c|c|c|c|c|c|c|c|c|c|c|c|}
\hline \multirow[b]{2}{*}{$\begin{array}{l}\text { Patient } \\
\text { No }\end{array}$} & \multirow[b]{2}{*}{ Sex } & \multirow[b]{2}{*}{$\begin{array}{l}\text { Age at } \\
\text { diagnosis }\end{array}$} & \multirow[b]{2}{*}{$\begin{array}{l}\text { Age at } \\
\text { relapse }\end{array}$} & \multirow[b]{2}{*}{$\begin{array}{l}\text { Time } \\
\text { missed } \\
\text { off } \\
\text { school }\end{array}$} & \multirow[b]{2}{*}{$\begin{array}{l}\text { Age } \\
\text { at } \\
\text { testing }\end{array}$} & \multicolumn{5}{|c|}{$\begin{array}{l}\text { Age equivalent performance levels } \\
\text { (maximum possible age equivalent score) }\end{array}$} & \multirow[b]{2}{*}{$\begin{array}{l}\text { Exam } \\
\text { (grades) } \dagger\end{array}$} & \multirow[b]{2}{*}{$\begin{array}{l}\text { Educationalemployment } \\
\text { statust }\end{array}$} \\
\hline & & & & & & $\begin{array}{l}\text { Single } \\
\text { word } \\
\text { reading } \\
(12: 6)\end{array}$ & $\begin{array}{l}\text { Prose } \\
\text { reading } \\
\text { (accuracy) } \\
(13: 0)\end{array}$ & $\begin{array}{l}\text { Prose } \\
\text { reading } \\
\text { (comprehension) } \\
(13: 0)\end{array}$ & $\begin{array}{l}\text { Spelling } \\
(15: 0)\end{array}$ & $\begin{array}{l}\text { Maths } \\
(14: 5)\end{array}$ & & \\
\hline 1 & $\mathbf{F}$ & $7: 0$ & $9: 7$ & $>1$ year & $15: 11$ & $12: 3$ & $12: 10$ & $9: 8$ & $12: 2$ & $11: 1$ & $\underset{\mathrm{E})}{\operatorname{GCSE}}(\mathrm{D}, \mathrm{C}$, & $\begin{array}{l}\text { FE college to take GCSEs } \\
(\mathrm{D}, \mathrm{D}, \mathrm{B}, \mathrm{C}, \mathrm{C})\end{array}$ \\
\hline 2 & $\mathbf{F}$ & $6: 9$ & $9: 11$ & 8 months & $15: 4$ & $12: 5$ & $11: 10$ & $>13: 0$ & $11: 2$ & $10: 5$ & $\begin{array}{l}\text { GCSE ( } 3 \text { pass, } \\
2 \text { fail) }\end{array}$ & BTEC (pass); unemployed \\
\hline 3 & $\mathbf{F}$ & $4: 6$ & $6: 6$ & $>1$ year & $11: 1$ & $<5: 0$ & $<5: 0$ & $<5: 0$ & $5: 1$ & $5: 10$ & & $\begin{array}{l}\text { Mainstream school with } \\
\text { statement of special } \\
\text { educational needs }\end{array}$ \\
\hline 4 & $\mathbf{M}$ & $1: 7$ & $4: 2$ & 1 year & $12: 6$ & $9: 3$ & $9: 4$ & $8: 8$ & $10: 5$ & $8: 3$ & & $\begin{array}{l}\text { Mainstream school with } \\
\text { statement of special } \\
\text { educational needs }\end{array}$ \\
\hline 5 & $\mathbf{M}$ & $2: 10$ & $\begin{array}{l}\text { (a) } 6: 7 \\
\text { (b) } 9: 10\end{array}$ & $>1$ year & $12: 3$ & $12: 6$ & $12: 10$ & $11: 11$ & $13: 3$ & $11: 6$ & & Mainstream school \\
\hline 6 & $\mathbf{M}$ & $5: 10$ & $7: 0$ & 6 months & $17: 9$ & $>12: 6$ & $9: 1$ & $9: 5$ & $12: 4$ & $>14: 5$ & $\begin{array}{l}\text { GCSE (6 pass, } \\
1 \text { fail) }\end{array}$ & $\begin{array}{l}\text { Completed } 16+\text { government } \\
\text { training scheme }\end{array}$ \\
\hline 7 & $\mathbf{M}$ & $4: 11$ & $\begin{array}{l}\text { (a) } 9: 9 \\
\text { (b) } 10: 10\end{array}$ & Minimal & $10: 5$ & $7: 6$ & $7: 2$ & $7: 11$ & $7: 8$ & $8: 3$ & & $\begin{array}{l}\text { Mainstream school with } \\
\text { statement of special } \\
\text { educational needs }\end{array}$ \\
\hline 8 & $\mathbf{M}$ & $3: 5$ & $10: 1$ & 2-3 months & 19:1 & $>12: 6$ & $>13: 0$ & $>13: 0$ & $14: 10$ & $>14: 5$ & $\begin{array}{l}\text { A levels (D, E, } \\
2 \text { fail) }\end{array}$ & Started BTEC course \\
\hline 9 & $\mathbf{M}$ & $3: 8$ & $8: 9$ & 1 year & $12: 9$ & $11: 10$ & $9: 6$ & $10: 9$ & $9: 9$ & $13: 4$ & & $\begin{array}{l}\text { Mainstream school with } \\
\text { statement of special } \\
\text { educational needs }\end{array}$ \\
\hline 10 & $\mathbf{M}$ & $3: 9$ & $5: 0$ & 6 months & 9:10 & $7: 5$ & $6: 2$ & $6: 4$ & $7: 1$ & $8: 8$ & & Mainstream school \\
\hline 11 & $\mathbf{M}$ & $3: 6$ & $8: 9$ & Minimal & $12: 11$ & $>12: 6$ & $>13: 0$ & $>13: 0$ & $13: 1$ & $>14: 5$ & & Mainstream school \\
\hline 12 & $\mathbf{M}$ & 4:5 & $8: 0$ & 2 years & $11: 0$ & $8: 4$ & $7: 11$ & $6: 11$ & $8: 8$ & $10: 1$ & & Mainstream school \\
\hline 13 & $\mathbf{F}$ & $2: 4$ & $6: 7$ & $2-3$ months & $8: 0$ & $6: 9$ & $5: 2$ & $5: 1$ & $6: 5$ & $6: 0$ & & $\begin{array}{l}\text { Mainstream school with } \\
\text { statement of special } \\
\text { educational needs }\end{array}$ \\
\hline 14 & $\mathbf{M}$ & $6: 0$ & $\begin{array}{l}\text { (a) } 8: 9 \\
\text { (b) } 11: 1 \\
\text { (c) } 14: 0 \\
\text { (d) } 16: 2 \\
\text { (e) } 17: 2\end{array}$ & $\begin{array}{l}\text { Stopped } \\
\text { attending } \\
\text { school } \\
\text { after third } \\
\text { relapse }\end{array}$ & $17: 0$ & $8: 0$ & $\begin{array}{l}\text { Not } \\
\text { completed }\end{array}$ & Not & $8: 0$ & $8: 10$ & None taken & Mainstream school \\
\hline
\end{tabular}

tGCSE = General Certificate of Secondary Education; FE=further education; BTEC=British Technician Education Council.

classroom. This support was not automatically provided, however, and in several instances was minimal. Of the five who had left school all were still living at home and none reported a desire to move away from their parents. Despite modest exam success all these young adults had below average levels of literacy and numeracy. Of the nine children still at school, only two were performing at age appropriate levels on measures of reading, spelling, and maths. The social outcome in terms of independence, employment, and peer relationships is generally poor.

It has been proposed that the somnolence syndrome, despite its self limiting nature, predicts subsequent neuropsychological deficits ${ }^{27}$ and the high rate of this disorder in the study group is in accord with this view. The mild neurological signs seen in this study are consistent with other investigators who have reported a range of neurological deficits while receiving treatment, ${ }^{28}$ six months after treatment, ${ }^{8}$ and five to seven years after treatment. ${ }^{49}$ Despite the high number of children displaying neurological signs, motor disabilities were mild and usually confined to hand function. The neurological impairment is consistent with a mild pyramidal deficit with the emphasis on the cortex being affected that is, dyspraxia rather than spasticity.

Verbal comprehension and tests of attention and memory were in the impaired range with respect to population norms. Poor performance on all measures was related to the time between initial diagnosis and relapse. Girls were more likely to show below average performance than boys on tests of attention and memory.

Previous studies have shown a positive correlation between earlier age at diagnosis and poorer outcome. ${ }^{30}$ We have also found that children who have received single doses of cranial radiotherapy at an early age are more likely to develop cognitive difficulties (Christie $\mathrm{D}$, et al, unpublished data). In this sample of children age at diagnosis was not a critical factor in neuropsychological outcome. Lower age at relapse (and second treatment) and the interval between treatments were significantly correlated with poorer outcome.

The separate roles of cranial radiotherapy and intrathecal methotrexate in the production of deficits in neurological or neuropsychological functioning is not clear. Although some workers suggest that the cranial radiotherapy effects are exacerbated by methotrexate, ${ }^{31}$ it is not clear whether this interaction is additive or synergistic. ${ }^{32}$ Higher numbers of methotrexate injections did not correlate with any of the outcome measures. The total dose of cranial radiotherapy was related to lower performance on the non-verbal measure of IQ in addition to receptive vocabulary. These results therefore provide moderate support for other studies that argue for the unique role of cranial radiotherapy in intellectual decline after treatment. ${ }^{33}$ The negative consequences of cranial radiotherapy have been recognised for some time and the most recent Medical Research Council trial (UKALL XI) has omitted presymptomatic cranial radiotherapy for all children with white blood cell counts less than 
$50 \times 10^{9} / 1$. Preventive CNS treatment is given as intrathecal methotrexate either with or without high dose intrathecal methotrexate. Therefore if cranial radiotherapy is needed after relapse the total dose of radiotherapy will ultimately be significantly less with, hopefully, a similar reduction in outcome morbidity.

Wheeler et al concluded 'there is a price to pay for cure with a higher price for retrieval therapy'. ${ }^{34}$ They compared outcome morbidity between a group receiving a single dose and a group which received a variety of retrieval therapies including testicular radiation and second doses of cranial, craniospinal, or total body irradiation before bone marrow transplantation. They found that overall residual morbidity for this group was $82 \%$ compared with $42 \%$ for the single dose group. Deficits included growth and endocrine failure, neurological deficits, seizures, and neuropsychological problems. A prospective study ${ }^{35}$ reported significant and progressive reductions in IQ after treatment for relapse. The small number of children who achieve successful remission after relapse means that care must be taken when emphasising differences in outcome in relation to treatment, given the heterogeneity of the treatment protocols. This study has highlighted areas of cognitive function that in this sample have been found to be at risk from different aspects of the treatment. It is therefore important that these findings are confirmed using larger, more homogeneous populations. In this study intellectual impairment and poor educational outcome is reported in $85 \%$ of the children. All the brain scans obtained after relapse show evidence of treatment related damage. Additional problems with cataracts (93\%), endocrine dysfunction $(100 \%)$, a range of neurological symptoms $(100 \%)$, and poor emotional adjustment confirm the high price of retrieval therapy in all aspects of the patients' lives and that of their families. Although the prognosis after relapse was previously poor but clearly defined, families are now faced with uncertainty about the effects of treatment and the overall outcome. What was once an acute and terminal disease is now a chronic illness with a range of long term effects which are as yet not fully understood.

1 Aur RJA, Simone J, Hustu HO, et al. Central nervou system therapy and combination chemotherapy of childhood lymphocytic leukaemia. Blood 1971; 37: 272-81.

2 Ponchedly C. Prophylactic CNS therapy in childhood acute leukaemia. Review of methods used. Am $\mathcal{F}$ Pediatr Hematol Oncol 1979; 1: 119-26.

3 Copeland DR, Dowell RE, Fletcher JM, et al. Neuropsychological test performance of pediatric cancer psychological test performance of pediatric cancer
patients at diagnosis and one year later. $\mathcal{F}$ Pediatr Psychol patients at diagnosis

4 Brouwers P, Riccardi R, Poplack DG, Fedio P. Attentional deficits in long term survivors of childhood acute lymphoblastic leukaemia (ALI). F Clin Neuropsychol 1984; 6: 325-36.
5 Peylan-Ramu N, Poplack DG, Pizzo PA, Adornato BT, DiChiro G. Abnormal CT scans of the brain in asymptomatic children with acute lymphocytic leukaemia after prophylactic treatment of the central nervous system with prophylactic treatment of the central nervous system with 1978; 298: 815-9.

6 Wilson DA, Nitschke R, Bowman ME, Chaffin MJ, Sexauer $\mathrm{CL}$, Prince JR. Transient white matter changes on MRI images in children undergoing chemotherapy for acute lymphoblastic leukaemia: correlations with neuropsychologic deficiencies. Radiology 1991; 180: 205-9.

7 McIntosh S, Klatskin EH, O'Brien RT, et al. Chronic neurologic disturbance in childhood leukemia. Cancer 1976; 37: 853-7.

8 Chessells JM, Cox TCS, Kendall B, Cavanagh NPC, Jannoun L, Richards S. Neurotoxicity in lymphoblastic leukaemia: comparison of oral and intramuscular methotrexate and two radiation doses. Arch Dis Child methotrexate and

9 Price RA, Jamieson PA. The central nervous system in childhood leukaemia II. Subacute leukoencephalopathy. Cancer 1975; 35: 306-18.

0 Gangji D, Reaman GH, Cohen SR, Bleyer WA, Poplack DG. Leukoencephalopathy and elevated levels of myelin basic protein in the cerebrospinal fluid of patients with acute lymphoblastic leukaemia. $N$ Engl F Med 1980; 303: 19-21.

11 Leiper AD, Chessells JM Acute lymphoblastic leukaemia under 2 years. Arch Dis Child 1986; 61: 1007-12.

12 Pinkerton CR, Chessells JM. Failed central nervous system prophylaxis in children with acute lymphoblastic prophylaxis in children with acute lymphoblastic 57: 553-61.

13 Berges J, Lezine I. The imitation of gestures. London: SIMP with Heinemann Medical, 1965. (Clinics in developmental medicine; No 18.)

14 LaFayette Instrument Company. Instructions for the 78010 hand dynamometer. Indiana: LaFayette, 1989

15 Annett $M$. The annett peg moving test of hand skill. Hull: University of Hull, 1986

16 Wechsler D. Wechsler intelligence scale for children - revised UK edition. Windsor: NFER Nelson, 1982.

17 Wechsler D. Wechsler adult intelligence scale. Sidcup, Kent: Psychological Corporation, 1986.

18 Gutkin TB. The WISC-R verbal comprehension, perceptual organisation and freedom from distractibility quotients: data for practitioners. Psychology in the Schools quotients: data for

19 Wechsler D. A standardised memory scale for clinical use. f Psychol 1945; 19: 87-95

20 Kimura D, McGlone J. Children's stories for testing LTM. In: Kimura D, McGlone J, eds. Neuropsychological test manual. London: DK Consultants, 1979.

21 Dunn LM, Dunn LM, Whetton C, Pinlitie D. The British picture vocabulary scale. Windsor: NFER Nelson, 1982.

22 Bishop D. Test for the reception of grammar. 2nd Ed. 1989.

23 Schonell F, Goodacre E. Schonell: graded word reading test. The psychology and teaching of reading. Edinburgh: test. The psychology and teach

24 Neale MD. Neale analysis of reading ability - revised British edition. Windsor: NFER Nelson, 1989

25 Schonell F. Schonell: graded word spelling test. Reading and spelling tests: handbook of instructions. Edinburgh: Oliver and Boyd, 1974

26 Elliot CD, Murray DJ, Pearson LS. British ability scales. Windsor: NFER Nelson, 1983.

27 Hanefield F, Riehm H. Therapy of acute lymphoblastic leukaemia in childhood: effects on the nervous system. Neuropaediatrie 1980; 11: 3-16.

28 McIntosh S, Fischer DB, Rothman SG, Rosenfield N, Lobel J, O'Brien RT. Intracranial calcifications in childhood leukaemia. F Pediatr 1977; 91: 909-13.

29 Poplack DG, Brouwers P. Adverse sequelae of central nervous system. Clin Oncol 1985; 4: 263-85.

30 Cousens $P$, Waters B, Said J, Stevens M. Cognitive effects of cranial irradiation in leukaemia: a survey and metaanalysis. F Child Psychol Psychiatry 1988; 29: 839-52.

31 Ochs J, Mulhern RK. Late effects of antileukaemic treatment. Pediatr Clin North Am 1988; 35: 815-33.

2 Dowell RE, Copeland DR, Francis DJ, Fletcher JM, Stovall $M$. Absence of synergistic effects of CNS treatments on neuropsychologic test performance among children. $\mathcal{F}$ Clin Oncol 1991; 9: 1029-36.

33 Fletcher JM, Copeland DR. Neurobehavioural effects of central nervous system prophylactic treatment of cancer in children. 7 Clin Exp Neuropsychol 1988; 10: 495-538.

34 Wheeler K, Leiper AD, Jannoun L, Chessells JM. Medical cost of curing childhood acute lymphoblastic leukaemia. BMF 1988; 296: 162-6.

35 Longeway K, Mulhern RK, Crisco J, et al. Treatment of meningeal relapse in childhood acute lymphoblastic leukemia: II. A prospective study of intellectual loss specific to CNS relapse and therapy. Am $\mathcal{F}$ Pediatr Hemato Oncol 1990; 12: 45-50. 